Article

\title{
Economic, Technological as Well as Environmental and Social Aspects of Local Use of Wood By-Products Generated in Sawmills for Energy Purposes
}

\author{
Katarzyna Mydlarz ${ }^{1, *}$ and Marek Wieruszewski ${ }^{2}$ D \\ 1 Department of Law and Organization of Agribusiness Enterprises, Faculty of Economics, Poznań University \\ of Life Sciences, Wojska Polskiego 28, 60-637 Poznań, Poland \\ 2 Department of Wood-Based Materials, Faculty of Forestry and Wood Technology, Poznań University of Life \\ Sciences, Wojska Polskiego 28, 60-637 Poznań, Poland; marek.wieruszewski@up.poznan.pl \\ * Correspondence: katarzyna.mydlarz@up.poznan.pl
}

check for updates

Citation: Mydlarz, K.; Wieruszewski, M. Economic, Technological as Well as Environmental and Social Aspects of Local Use of Wood By-Products Generated in Sawmills for Energy Purposes. Energies 2022, 15, 1337. https://doi.org/10.3390/en15041337

Academic Editor: Byong-Hun Jeon

Received: 30 December 2021

Accepted: 10 February 2022

Published: 12 February 2022

Publisher's Note: MDPI stays neutral with regard to jurisdictional claims in published maps and institutional affiliations.

Copyright: (C) 2022 by the authors. Licensee MDPI, Basel, Switzerland. This article is an open access article distributed under the terms and conditions of the Creative Commons Attribution (CC BY) license (https:/ / creativecommons.org/licenses/by/ $4.0 /)$.

\begin{abstract}
The article is the first in a series of works presenting the potential and possibilities of using for energy purposes wood waste and wood by-products generated at various stages of production in companies of the wood industry. The management of all wood waste and wood by-products is a pending issue due to the growing importance of the circular economy and broadly understood environmental protection. It is the environmental aspects and the climate targets defined by the EU that are the basis to determine the precise courses of action for the Member States and, as a result, also for companies. The article proves that regardless of the decisions taken by governments of individual countries in terms of broadly understood environmental protection, companies are free to implement pro-environmental solutions as part of their business activity. Due to the broad subject of the management of waste and by-products generated in different units of the wood industry, the possibilities of their use in terms of energy in primary wood processing companies-sawmills-are presented first. On the example of selected entities, the energy potential and possibilities of generating energy from renewable sources taking into account the principles of circular economy are presented. The possibilities of optimising production by improving redistribution of thermal energy, which may result in improving the economic efficiency of the assessed enterprises, were indicated.
\end{abstract}

Keywords: circular economy; woody biomass; bioenergy; economic; environmental and social benefits; energy independence

\section{Introduction}

Intense growth in production and consumption escalates the demand for natural resources and negative impact on the natural environment. The above generates greater demand for energy and is the reason for a growing amount of waste [1,2]. At the same time, many societies, mainly in Western Europe, become more and more aware of the negative consequences of unrestricted use of the goods of nature. That refers not only to the increased demand for raw materials but also to the level of environmental pollution formed as a result of the scale of production and energy policy implemented by many countries around the world. The outcomes of the research conducted by scientists prompt the authorities to make decisive changes in that area [3]. The changes are implemented in two ways: "top-down"-based on created legal regulations [4] and "bottom-up" — as a result of spontaneous decisions and actions taken locally by producers and consumers whose environmental awareness is taken into account while product decisions are made and company policy introduced. Efforts are made to maximise the use of raw materials and consumables in the production process and to transform from the linear to the circular economy, the so-called closed-loop economy, the main maxim of which is "zero waste" [5-7]. The idea of maximising the use of raw materials, especially renewable ones, mainly in the event of their shortage, has already become the way 
of thinking and the direction of actions of many institutions and entities in the processing industry [8]. That innovative trend, due to the specificity and nature of raw materials used for production, is applicable to the wood industry. The timber industry may be the best example of the application of such solutions as there are opportunities for complete utilisation of raw materials in that sector. Due to the nature of production, the waste and by-products that are generated by the enterprises are used by that particular company or by other branches of that industry. With regards to the wood industry, the framework of the circular economy is determined by the cascading use of resources, which can be defined as: "the efficient use of resources by using by-products and recycled materials to expand the total availability of biomass within a given system" [9]. In practice, the above means: "manufacture of wood products, extension of the useful life of products, reuse, recycling, generation of bioenergy, and disposal of waste" [10]. As a result, a wood product, after its service life related to its life cycle is extended to a maximum, can again become a source of valuable material $[11,12]$ which ultimately leads to a lower level of consumption of primary wood [13,14]. Finally, at the last stage of the closed-loop economy applied to companies in the wood industry, there is the energy aspect, which means that any product made from wood can, after going through all phases of the life cycle, become a source of energy [15]. Such opportunities and actions translate directly into economic and environmental benefits for the companies that apply those solutions. Such solutions may also be implemented to compensate sectors of the economy that are not environmentally neutral, e.g., the energy sector [16]. Therefore, it is extremely important to apply at all stages of processing, finishing and protecting wooden elements, materials and measures that are environmentally neutral or that reduce the harmful impact of the entity on the environment, so that the combustion process takes place with the least possible interference in the environment. With regards to the above, within the wood industry, the greatest opportunities are in the sawmill industry. It is during the elemental processing of wood that both finished products and by-products are generated which, due to the lowest level of processing and chemical treatment, can be most easily used for energy purposes. The goal of many sawmill companies is to search for and apply solutions that allow the wood to be processed into environmentally friendly products that will not generate waste at any stage of the value chain, starting with wood raw material to the final finished product [17]. The purpose of the activities is to constantly improve profitability with the application of resource-efficient, innovative solutions. The key issue is the ability to adapt to the current needs of the global economy in a flexible way and to fit into the latest trends in the market. Hence, the response of wood-processing plants to global problems, e.g., the ability to provide access to affordable, sustainable and green energy. However, in the majority of the cases, the actions of the companies are mostly limited to ensuring their own energy independence. The generated heat energy is always used, first of all, for the internal needs of the company, i.e., mainly to dry sawn timber in the drying rooms or to ensure the right temperature in the buildings. Once the energy demand of the company is met, the surplus heat or electricity goes to the local market. Thanks to such solutions, the local community benefits from green energy and the quality of life of the residents improves due to clean air. Such courses of action are also supported by scientific research. In Sweden, for example, simulation studies have been performed with regards to heat and electricity demand with the use of different technologies applied in sawmills. Based on the research, it was concluded that the widespread implementation of energy recovery technologies available in Swedish sawmills can lead to significant savings of biomass allocated for other purposes in society, which confirms the economic as well as the environmental and social aspects [18].

The implementation of the aforementioned solutions contributes to the reduction in the consumption of both electricity and heat from fossil fuels. Such real actions introduced by companies, even on a small scale, are an opportunity to achieve better and better environmental indicators on a global scale. The actions are also necessary due to the fact that the values of those indicators are constantly increased by the EU authorities The 2030 climate and energy framework, adopted by the European Parliament, identifies three key targets to be met between 2021 and 2030: 
- reduction in greenhouse gas emissions by at least 40\% compared to the level in 1990

- ensuring the share of energy from renewable sources in the total energy consumption at a minimum level of $32 \%$

- $\quad$ increasing energy efficiency by at least 32.5\% [19].

Those goals show the directions of development for the economies of the Member States and, consequently, the directions for the enterprises that are involved in production processes. Hence the decision to take up the topic, especially since there is no information in the literature and scientific research on the economic balance of the use of wood biomass for energy purposes. Most of the research is related to the utilisation of post-production biomass and verification of energy demand in the processing of round wood by gasification or combustion [20-25]. It can be assumed that annually, in Poland, the quantity of byproducts that are potentially suitable for energy purposes is approximately $40 \%$ of the processed wood. Efficient utilisation of that raw material is possible thanks to technologies, of combustion and its use to generate electricity and industrial heat. To effectively assess the sustainability of the use of biomass, a resource abundance analysis and economic calculation of biomass for electricity generation must be performed.

The purpose of this study is to indicate the options available of using wood byproducts to generate heat and electrical energy in sawmills. The assessment of justification of the usage by-products of sawmill processing was carried out in relation to the conditions of a selected Central European country with a significantly fragmented structure of sawmill sector. The scope of the research indicated the economic justification for biomass usage for both thermal energy and electricity production within the own circular activity of sawmills.

\section{Materials and Methods}

To assess the energy potential and energy costs, sawmills operating in Poland were selected, as they are the first link in the round wood processing chain. In the article, the sawmills are classified taking into account the quantity of processed wood. For the assessed group of sawmills, different types of by-products generated during the production are specified, their calorific value and approximate energy costs. The production structure of the assessed enterprises was analysed from the point of view of the internal circular economy of the processing of round raw material into sawn material and various types of by-products. A simulation analysis was performed with regards to circulation of material flow in the entities in terms of management of wood by-products and the possibilities of implementation of such solutions in other enterprises of the wood industry were indicated. To present the correlation between each data, a statistical method, Pearson's r, was used.

With regards to the sawmill industry in Poland, addressing the issue of the use of by-products generated during the production process for energy purposes is important, i.e., because of the poorly-developed national energy policy and still too low, taking into account the EU requirements, share of renewable energy in the national economy.

The conducted study made it possible to determine, i.e.,:

- the structure of fuels used to generate electricity and heat in Poland.

- the amount of obtained and processed wood as a source of biomass-including timber, as well as export and import of wood.

- the amount of wood by-products generated in primary wood processing enterprises and their use.

- the calorific value of individual groups of waste and by-products-to determine the calorific value of by-products, the data on the calorific value of the main types of wood and bark and their share in the processed material in national sawmills were used (Table 1).

- the energy demand of sawmills and their ability to generate energy on their own information on the demand for electricity was obtained from a direct survey conducted in selected sawmills that represented one of the four groups specified depending on the level of wood processing. 
Table 1. Calorific value of selected wood materials with an average moisture content of $35 \%$.

\begin{tabular}{ccc}
\hline Type of Wood & $\begin{array}{c}\text { Calorific Value of Wood } \\
{\left[\mathrm{GJ} / \mathbf{m}^{\mathbf{3}}\right]}\end{array}$ & $\begin{array}{c}\text { Share of Wood in Harvest } \\
{[\%]}\end{array}$ \\
\hline Pine & 7.44 & 61.0 \\
\hline Spruce & 7.08 & 10.0 \\
\hline Beech & 10.09 & 6.9 \\
\hline Oak & 10.09 & 6.6 \\
\hline Birch & 9.03 & 4.7 \\
\hline other & 7.08 & 10.8 \\
\hline Bark & 0.0185 & - \\
\hline
\end{tabular}

Source: Reproduced from [26,27]. Report on the State of Forests in Poland (2019).

Depending on the quantity of processed wood, sawmills were divided into four groups:

- group I-processing of up to $5000 \mathrm{~m}^{3} /$ year.

- group II-processing of 5000-50,000 $\mathrm{m}^{3} /$ year.

- group III-processing of 50,000-100,000 $\mathrm{m}^{3} /$ year.

- group IV-processing of more than $100,000 \mathrm{~m}^{3} /$ year.

- the electricity costs incurred by sawmills.

- the potential value of electricity generated from biomass.

- the potential value of thermal energy generated from biomass.

- the potential opportunities for sawmills to transfer excess energy to the local community.

To assess the impact of processed by-products on the energy potential of biomass, the share and calorific value of bark obtained from the processed round wood were taken into account. The indicator of the most popular type of wood in processing was used, i.e., pine wood, in the case of which approximately $8 \%$ of bark is generated in relation to the quantity of round wood (Table 2).

Table 2. Percentage share of bark in long wood.

\begin{tabular}{cc}
\hline Type of Wood & Percentage Share of Bark \\
\hline Pine & 8.0 \\
\hline Spruce & 8.5 \\
\hline Fir & 10.0 \\
\hline Beech & 6.3 \\
\hline Oak & 21.2 \\
\hline Alder & 21.8 \\
\hline Birch & 11.5 \\
\hline
\end{tabular}

Source: Reproduced from [28], Encyclopedia Polish Forests (2021).

In the assessments of biomass, an average content of moisture of 35\% was assumed and, due to the increasing efficiency of biomass combustion, the potential calorific value of the fuel was set at the level of $100 \%$, taking into account a $33 \%$ level of cogeneration of electricity.

\section{Results}

\subsection{Potential of Biomass Used as a Fuel for Heat Production}

Based on the statistics, the share of energy generated from renewable sources, including biomass, was significantly increasing in Poland in the period from 2015 to 2019 (Table 3). The above indicates a progressive reorganisation of the way in which energy sources are used, forced by economic and environmental requirements, as well as the growing awareness and interest of businesses in sources of energy alternative to fossil fuels. 
Table 3. Structure of fuels used to generate thermal energy in \%.

\begin{tabular}{|c|c|c|c|c|c|}
\hline Type of Fuel & 2015 & 2016 & 2017 & 2018 & 2019 \\
\hline Black coal & \multirow{2}{*}{74.6} & 73.35 & 72.21 & 71.27 & 69.88 \\
\hline Lignite & & 1.62 & 1.59 & 1.19 & 1.12 \\
\hline Light fuel oil & \multirow{2}{*}{5.9} & 0.22 & 0.28 & 0.22 & 0.24 \\
\hline Heavy fuel oil & & 5.43 & 4.85 & 4.53 & 4.35 \\
\hline Methane-rich natural gas & \multirow{2}{*}{7.8} & 5.29 & 6.87 & 6.8 & 7.54 \\
\hline Nitrogen-rich natural gas & & 1.9 & 1.66 & 1.82 & 1.93 \\
\hline biomass & \multirow{3}{*}{7.4} & 7.42 & 7.42 & 7.99 & 9.23 \\
\hline biogas & & 0.03 & 0.05 & 0.03 & 0.04 \\
\hline other renewable energy sources & & 0.14 & 0.14 & 0.17 & 0.2 \\
\hline Municipal solid waste & \multirow{3}{*}{4.3} & 0.46 & 1.18 & 1.46 & 1.73 \\
\hline Non-renewable industrial waste & & 0.15 & 0.09 & 0.24 & 0.24 \\
\hline other types of fuel & & 3.99 & 3.65 & 4.29 & 3.51 \\
\hline
\end{tabular}

Based on the data presented in Table 3, during the analysed period, not only is the share of renewable energy in the fuel structure significant but there is also an increase in the share of that type of energy over particular years. Taking into account the listed types of fuel, it is renewable fuels such as, i.e., biomass that rank second after coal fuels. Since wood biomass is included in the broadly understood biomass, which is an energy fuel, the authors of the article focused on that particular type of fuel in further considerations.

\subsection{Wood Biomass Resources from Sawmills}

The starting point for further analysis was the comparison of the data on obtained and sold wood-including timber, also exported and imported. The comparison covers the period from 2010 to 2020 (Figure 1).

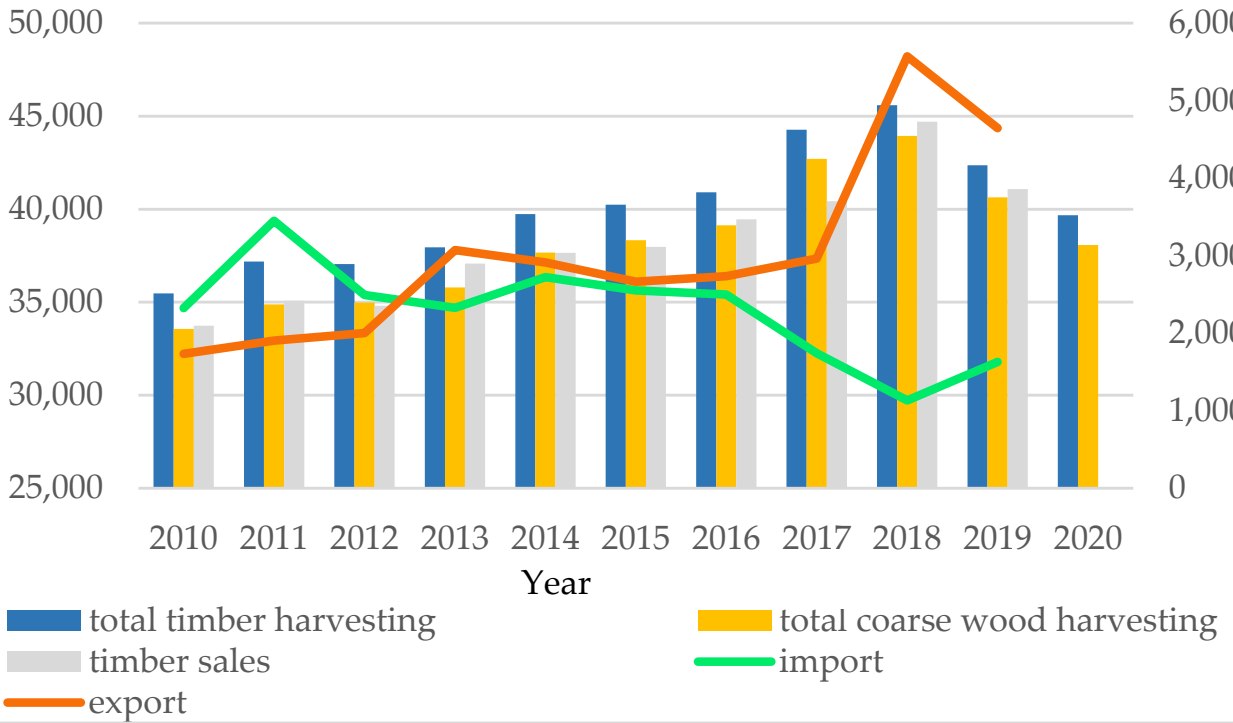

Figure 1. Acquisition, sale, export and import of wood Source: own elaboration based on Statistical Yearbooks of Forestry Source: own elaboration based on available publications [34-37]. 
Based on Figure 1, the amount of obtained and sold wood steadily increased from 2010 to 2018, which also indicates an increasing share of wood biomass during this period. The significantly higher quantity of obtained wood in the period from 2017 to 2019, is the result of the works performed by foresters to clean up the large area of the forest after the "hurricane of the century". Due to the hurricane, trees were blown over by the wind or broken and an additional 8.5 million $\mathrm{m}^{3}$ of wood was obtained (equivalent to $20 \%$ of all-year acquisition of wood in the State Forests) [38]. Consequently, exports of wood increased, and the quantity of imported wood was much lower during that time. However, since 2018, there has been a noticeable decline in timber harvest.

To assess the possibilities of using the by-products that are generated at the initial stage of wood processing, the amount of processed wood was determined first.

$$
\mathrm{D}_{\mathrm{p}}=\mathrm{D}_{\mathrm{s}}+\mathrm{D}_{\mathrm{i}}-\mathrm{D}_{\mathrm{e}}
$$

$\mathrm{D}_{\mathrm{p}}$ - processed wood

$\mathrm{D}_{\mathrm{s}}$ - wood allocated for sale by LP

$\mathrm{D}_{\mathrm{i}}$-imported wood

$\mathrm{D}_{\mathrm{e}}$ - exported wood

The amount of wood processed by timber companies in individual years is shown in Figure 2.

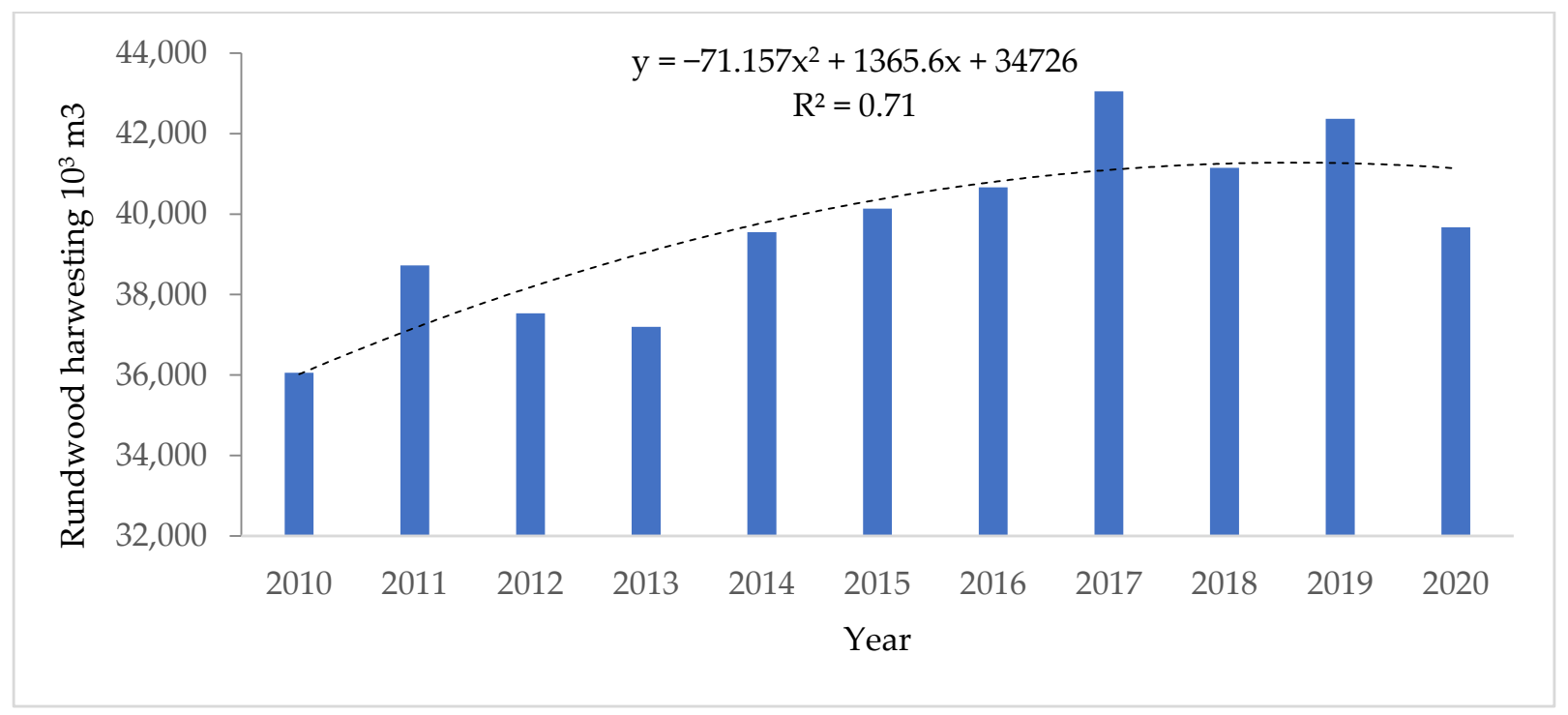

Figure 2. The amount of round wood processed in Poland. Source: own elaboration.

As can be seen in Figure 2, Poland currently processes approximately 40 million $\mathrm{m}^{3}$ of wood per year, of which sawmills process approximately 25 million $\mathrm{m}^{3}$ [34]. The characteristic of changes in the acquisition of wood is not linear. It can be defined with a formula: $y=-71.157 x^{2}+1365.6 x+34726$ which indicates a gradual decline in the amount of processed raw material. The most popular and most widely processed wood raw material is pine. It accounts for approximately $61 \%$ of the processed raw material. Other popular types of wood are spruce $5.6 \%$, fir $4.4 \%$, beech $6.9 \%$, oak $6.6 \%$, and birch $4.7 \%$, with the remaining ones accounting for a total of $10.8 \%$ [34].

Knowing the total amount of processed wood, it is possible to determine the amount of wood by-products generated by sawmills. To do so, many factors must be taken into account, including the type and grade of processed raw material or the type of production. Thus, taking the above into account, as well as considering the yield of the raw material, it is possible to indicate, with some simplification, the types of generated wood by-products and their estimated quantity (Table 4). 
Table 4. Types and estimated quantity of generated wood by-products.

\begin{tabular}{|c|c|c|}
\hline Type of Production & Type of the Waste & $\begin{array}{c}\text { Estimated Quantity of By-Products as a Percentage Share } \\
\text { of the Initial Raw Material [\%] }\end{array}$ \\
\hline Sawmill industry & $\begin{array}{l}\text { Bark } \\
\text { woodchips, sawdust, wood } \\
\text { pellets }\end{array}$ & $\begin{array}{c}\text { approximately } 8 \% \\
\text { approximately } 30 \text { (wood chips approximately } 18 \% \text { ) } \\
10 \%\end{array}$ \\
\hline
\end{tabular}

Source: own elaboration based on available publications [39-41].

Taking into account the quantity of wood processed by individual sawmills, the intended use of wood by-products, the so-called woody biomass was determined (Table 5).

Table 5. Use of generated wood biomass.

\begin{tabular}{|c|c|c|c|c|}
\hline \multirow{2}{*}{ Form of Biomass } & \multicolumn{4}{|c|}{ Sawmills Processing Round Wood [m³/year]. } \\
\hline & up to 5000 & $5000-50,000$ & $50,000-100,000$ & over 100,000 \\
\hline Bark & Combustion & Sale for horticulture & $\begin{array}{l}\text { Sale for horticul- } \\
\text { ture/combustion }\end{array}$ & $\begin{array}{l}\text { Sale for horticul- } \\
\text { ture/combustion }\end{array}$ \\
\hline $\begin{array}{l}\text { Chunk wood waste: } \\
\text { wood chips, wood } \\
\text { shavings, wane }\end{array}$ & Combustion & $\begin{array}{l}\text { Combustion/Sale to } \\
\text { wood panel plants } \\
\text { (wood chips) }\end{array}$ & $\begin{array}{c}\text { Sale to wood panel } \\
\text { plants (wood } \\
\text { chips)/pellet, briquette } \\
\text { produc- } \\
\text { tion/combustion }\end{array}$ & $\begin{array}{l}\text { Sale to wood panel } \\
\text { plants (wood } \\
\text { chips)/pellet, briquette } \\
\text { production }\end{array}$ \\
\hline $\begin{array}{c}\text { Sawdust and wood } \\
\text { shavings }\end{array}$ & Combustion & Combustion & $\begin{array}{l}\text { Combustion/Pellet } \\
\text { production }\end{array}$ & $\begin{array}{l}\text { Combustion/Pellet } \\
\text { production }\end{array}$ \\
\hline
\end{tabular}

Source: own elaboration.

The profitability of processing waste and wood by-products depends on a number of factors such as, e.g., quantity, form, market demand, transport costs, external energy costs and energy demand of a given plant. Table 5 proves that the larger the sawmills, the greater the possibility of selling by-products, e.g., to wood panel plants or converting them into energy material: pellets or briquettes. In turn, in smaller business entities, the by-product material is most often used directly for energy purposes.

Thus, to indicate the potential amount of woody biomass generated in the different sawmill groups, it is necessary to consider their structure (Table 6).

Table 6. Quantity of processed wood and by-products generated in 2019.

\begin{tabular}{|c|c|c|c|c|c|c|}
\hline \multirow{2}{*}{$\begin{array}{c}\text { Processed } \\
\text { Quantity } \\
\text { [thousand } \mathbf{m}^{3} \text { ] }\end{array}$} & \multicolumn{2}{|c|}{ Sawmill Structure } & \multirow{2}{*}{$\begin{array}{l}\text { Wood } \\
\text { Consumption } \\
\text { [thousand } \mathrm{m}^{3} \text { ] }\end{array}$} & \multirow{2}{*}{$\begin{array}{c}\text { Timber } \\
\begin{array}{c}\left.\text { thousand } \mathrm{m}^{3}\right] \\
(55 \%)\end{array}\end{array}$} & \multirow{2}{*}{$\begin{array}{c}\text { By-Products } \\
\begin{array}{c}\left.\text { thousand } \mathrm{m}^{3}\right] \\
(40 \%)\end{array}\end{array}$} & \multirow{2}{*}{$\begin{array}{c}\begin{array}{c}\text { Desorption } \\
\text { Loss }\end{array} \\
{\left[\begin{array}{c}\left.\text { thousand } \mathrm{m}^{3}\right] \\
(5 \%)\end{array}\right.}\end{array}$} \\
\hline & [pcs.] & {$[\%]$} & & & & \\
\hline up to 5 & 5678 & 93.33 & 5220.75 & 2871.4 & 2088.3 & 261.04 \\
\hline $5.01-50.00$ & 381 & 6.26 & 5670 & 3118.5 & 2268.0 & 283.50 \\
\hline $50.01-100.00$ & 15 & 0.25 & 1125 & 618.7 & 450.0 & 56.25 \\
\hline $100.01-$ & 10 & 0.16 & 4500 & 2475.0 & 1800.0 & 225.00 \\
\hline Total & 6084 pcs. & 100 & $16,515.75$ & 9083.6 & 6606.3 & 825.79 \\
\hline
\end{tabular}

Source: own elaboration based on available publications [42].

The largest group of sawmills in Poland are those with a processing capacity of up to $5000 \mathrm{~m}^{3}(93.33 \%)$, the smallest group are sawmills with a processing capacity over $100,000 \mathrm{~m}^{3}(0.16 \%)$. However, the quantity of wood processed in both groups of sawmills is very similar. That confirms the diverse technological and investment capability across 
the groups. Analysing other data from Table 6 and taking into consideration the types of wood processed in Poland and the types of waste generated during processing (Table 4), the types of generated by-products were determined (Table 7).

Table 7. Quantity of by-products generated by sawmills during wood processing.

\begin{tabular}{|c|c|c|c|c|c|c|c|c|}
\hline \multirow{3}{*}{$\begin{array}{c}\text { Processed } \\
\text { Quantity }\end{array}$} & \multirow{3}{*}{$\begin{array}{c}\text { Wood } \\
\text { Consumption }\end{array}$} & \multicolumn{4}{|c|}{ By-Products } & \multirow{3}{*}{$\begin{array}{l}\text { Bark } \\
(8 \%)\end{array}$} & \multirow{3}{*}{$\begin{array}{c}\text { Total by- } \\
\text { Products + } \\
\text { Bark }\end{array}$} & \multirow{3}{*}{$\begin{array}{c}\text { Total By- } \\
\text { Products + } \\
\text { Bark per } \\
\text { Unit }\end{array}$} \\
\hline & & \multirow{2}{*}{$\begin{array}{l}\text { Total } \\
(40 \%)\end{array}$} & \multicolumn{2}{|c|}{$\begin{array}{c}\text { Chunk Wood Waste } \\
(30 \%)\end{array}$} & \multirow{2}{*}{$\begin{array}{c}\text { Sawdust } \\
\text { and Wood } \\
\text { Shavings } \\
(\mathbf{1 0 \% )}\end{array}$} & & & \\
\hline & & & $\begin{array}{l}\text { Wood } \\
\text { Chips } \\
(\mathbf{1 8 \%})\end{array}$ & $\begin{array}{l}\text { Other } \\
(12 \%)\end{array}$ & & & & \\
\hline \multicolumn{9}{|c|}{ [thousand $\mathrm{m}^{3}$ ] } \\
\hline up to 5 & 5220.75 & 2088.30 & - & 1566.23 & 522.08 & 417.66 & 2505.96 & 0.44 \\
\hline $5.01-50.00$ & 5670.00 & 2268.00 & 1020.60 & 680.40 & 567.00 & 453.60 & 2721.60 & 7.14 \\
\hline $50.01-100.00$ & 1125.00 & 450.00 & 202.50 & 135.00 & 112.50 & 90.00 & 540.00 & 36.00 \\
\hline over 100.01 & 4500.00 & 1800.00 & 1350.00 & - & 450.00 & 360.00 & 2160.00 & 216.00 \\
\hline Total & $16,515.75$ & 6606.30 & 2573.10 & 2381.63 & 1651.58 & 1321.26 & 7927.56 & 1.30 \\
\hline
\end{tabular}

Source: own elaboration based on available publications [39,40].

\subsection{Determining the Energy Potential of Woody Biomass}

In the subsequent section of the article, the calorific value of particular by-products generated during the initial stage of processing of wood was determined (Table 8). To calculate the calorific value, conversion factors were used, taking into account the type of wood from which by-products were generated (Table 1) and the moisture content of $35 \%$, which can be considered an average value for by-products generated by sawmills.

Table 8. Calorific value of by-products generated during wood processing by sawmills.

\begin{tabular}{|c|c|c|c|c|c|}
\hline \multirow{3}{*}{$\begin{array}{l}\text { Processed } \\
\text { Quantity }\end{array}$} & \multicolumn{3}{|c|}{ Calorific Value of By-Products } & \multirow{3}{*}{ Bark } & \multirow{3}{*}{ Total By-Products + Bark } \\
\hline & \multicolumn{2}{|c|}{ Chunk Wood Waste } & \multirow{2}{*}{$\begin{array}{c}\text { Sawdust and } \\
\text { Wood Shavings }\end{array}$} & & \\
\hline & Wood Chips & Other & & & \\
\hline [thousand $\mathrm{m}^{3}$ ] & [GJ] & [GJ] & [GJ] & [GJ] & [GJ] \\
\hline up to 5 & - & $12,212,796$ & $4,070,932$ & $2,130,066$ & $18,413,794$ \\
\hline $5.01-50.00$ & 1025 & $5,305,487$ & $4,421,239$ & $2,313,360$ & $12,041,111$ \\
\hline $50.01-100.00$ & 1579 & $1,052,676$ & 877,230 & 459,000 & $2,390,485$ \\
\hline over 100.01 & 10,527 & - & $3,508,920$ & 6660 & $3,526,107$ \\
\hline Total & 13,131 & $18,570,959$ & $12,878,321$ & $4,909,086$ & $36,371,497$ \\
\hline
\end{tabular}

Source: own elaboration.

Knowing the caloric value of by-products (Table 8 ) and the number of sawmills, the energy potential of wood by-products generated in sawmills of different processing capacity was determined (Table 9). 
Table 9. Energy potential of wood by-products generated during wood processing by sawmills.

\begin{tabular}{|c|c|c|c|c|c|c|c|}
\hline \multirow{3}{*}{$\begin{array}{l}\text { Processed } \\
\text { Quantity }\end{array}$} & \multirow{3}{*}{$\begin{array}{l}\text { Number of } \\
\text { Companies } \\
\text { Based on LP }\end{array}$} & \multirow{3}{*}{$\begin{array}{l}\text { Energy Potential of Wood } \\
\text { By-Products Per Unit + Bark }\end{array}$} & \multicolumn{4}{|c|}{ Energy Potential of Wood By-Products } & \multirow{3}{*}{ Bark } \\
\hline & & & \multirow{2}{*}{$\begin{array}{l}\text { Total By-Products } \\
\text { + Bark }\end{array}$} & \multicolumn{2}{|c|}{ Chunk Wood Waste } & \multirow{2}{*}{$\begin{array}{c}\text { Sawdust and } \\
\text { Wood Shavings }\end{array}$} & \\
\hline & & & & Wood Chips & Other & & \\
\hline [thousand $\mathrm{m}^{3}$ ] & [pcs.] & [GJ] & [GJ] & [GJ] & [GJ] & [GJ] & {$[\mathrm{GJ}]$} \\
\hline up to 5 & 5678 & 3243 & $18,413,794$ & - & $12,212,796$ & $4,070,932$ & $2,130,066$ \\
\hline $5.01-50.00$ & 381 & 31,604 & $12,041,111$ & 1025 & $5,305,487$ & $4,421,239$ & $2,313,360$ \\
\hline 50.01-100.00 & 15 & 159,366 & $2,390,485$ & 1579 & $1,052,676$ & 877,230 & 459,000 \\
\hline over 100.01 & 10 & 352,611 & $3,526,107$ & 10,527 & - & $3,508,920$ & 6660 \\
\hline Total & 6084 & 546,823 & $36,371,497$ & 13,131 & $18,570,959$ & $12,878,321$ & $4,909,086$ \\
\hline
\end{tabular}

Source: own elaboration.

\subsection{Determination of the Potential Value of Electricity and Heat Produced from Woody Biomass}

Taking into account the energy aspect, for further considerations, it is important to determine the energy demand of each group of sawmills. The demand was determined based on the capacity of installed equipment taking into account the average daily energy demand and the operation of the devices $16 \mathrm{~h}$ per day, 20 days per month and 12 months per year. Initial energy demand was determined based on information received from selected sawmills and manufacturers of complete sawmill lines. For calculations, to standardise the units, the following formula was used: $1 \mathrm{KWh}=0.0036 \mathrm{GJ}$ (Table 10).

Table 10. Total energy demand of each group of sawmills.

\begin{tabular}{ccc}
\hline $\begin{array}{c}\text { Groups of Sawmills } \\
\text { Depending on the Quantity } \\
\text { of Processed Material }\end{array}$ & Total Energy Demand [kWh] & Total Energy Demand [GJ] \\
\hline $\begin{array}{c}\text { Sawmills with the quantity of } \\
\text { processed material } \\
\text { up to } 5000 \mathrm{~m}^{3} / \text { year }\end{array}$ & 76,800 & 276.48 \\
\hline $\begin{array}{c}\text { Sawmills with the quantity of } \\
\text { processed material } \\
5000-50,000 \mathrm{~m}^{3} / \text { year }\end{array}$ & 192,000 & 691.20 \\
\hline $\begin{array}{c}\text { Sawmills with the quantity of } \\
\text { processed material }\end{array}$ & $1,920,000$ & 6912.00 \\
$50,000-100,000 \mathrm{~m}^{3} /$ year & & $41,472.00$ \\
\hline $\begin{array}{c}\text { Sawmills with the quantity of } \\
\text { processed material over } \\
100,000 \mathrm{~m}^{3} / \text { year }\end{array}$ & $11,520,000$ & \\
\hline Source: own elaboration. & & \\
\hline
\end{tabular}

Knowing the estimated total energy demand of individual sawmills and having energy potential of wood by-products and bark data, the share of electricity and heat that can be obtained from the combustion of biomass was determined (Table 11).

The rates for 2020 and 2021 established by the Energy Regulatory Office in Poland, which is the central body of state administration operating under the Energy Law of 10 April 1997, were used to determine the costs of thermal energy incurred by sawmills. According to that institution, the average unit price for heat generation by licensed companies during that period was PLN 44.33/GJ and the average unit transmission price for all heating systems was PLN 19/GJ. In turn, the average price per 1 MWh according to the Energy Regulatory Office in Poland in the last quarter of 2021 was PLN 255.99 [43]. That indicator was used to calculate the average cost of electricity for sawmills taking into account the formula:

$$
1 \mathrm{MWh}=3.6 \mathrm{GJ}
$$


The share of electricity obtained from the combustions of biomass and the potential value of electricity and heat generated from biomass (Table 11) indicate the profitability of using power generators in all groups of sawmills. However, the decision on whether to convert the generated heat energy into electricity depends largely on the market prices for both types of energy and the costs associated with purchasing generators.

Table 11. Average energy costs incurred by sawmills per year.

\begin{tabular}{|c|c|c|c|c|c|c|c|}
\hline $\begin{array}{c}\text { Processed } \\
\text { Quantity }\end{array}$ & $\begin{array}{l}\text { Total Energy } \\
\text { Demand }\end{array}$ & $\begin{array}{c}\text { Average } \\
\text { Electricity } \\
\text { Costs } \\
\text { Incurred by } \\
\text { Sawmills }\end{array}$ & $\begin{array}{c}\text { Energy } \\
\text { Potential of } \\
\text { Wood } \\
\text { By-Products } \\
\text { + Bark } \\
\text { by Unit }\end{array}$ & $\begin{array}{l}\text { Share of } \\
\text { Electricity } \\
\text { Obtained } \\
\text { from the } \\
\text { Combustion } \\
\text { of Biomass } \\
\text { (1/3)_by } \\
\text { Unit* }\end{array}$ & $\begin{array}{l}\text { Potential } \\
\text { Value of } \\
\text { Electricity } \\
\text { Generated } \\
\text { from } \\
\text { Biomass }\end{array}$ & $\begin{array}{l}\text { Quantity of } \\
\text { Heat } \\
\text { Energy-per } \\
\text { Unit at } 100 \% \\
\text { Efficiency }\end{array}$ & $\begin{array}{l}\text { Potential } \\
\text { Value of } \\
\text { Heat Energy } \\
\text { Generated } \\
\text { from } \\
\text { Biomass }\end{array}$ \\
\hline $\begin{array}{c}\text { [thousand } \\
\mathrm{m}^{3} \text { ] }\end{array}$ & [GJ] & [PLN] & [GJ] & [GJ] & [PLN] & [GJ] & [PLN] \\
\hline up to 5 & 276 & 19,660 & 3243 & 1081 & 76,868 & 2162 & 136,927 \\
\hline $5.01-50.00$ & 691 & 49,150 & 31,604 & 10,535 & 749,102 & 21,069 & $1,334,390$ \\
\hline $50.01-100.00$ & 6912 & 491,501 & 159,366 & 53,122 & $3,777,409$ & 106,244 & $6,728,773$ \\
\hline over 100.01 & 41,472 & $2,949,005$ & 352,611 & 117,537 & $8,357,852$ & 235,074 & $14,888,006$ \\
\hline
\end{tabular}

\section{Discussion}

The performed analyses prove that the sawmill industry is able to make use of all generated by-products at each stage of processing of raw wood or its main products. Based on the aforementioned data, it is possible to indicate the estimated amount of heat energy that can be used for the internal needs of a company and transmitted outside the entity, e.g., to local consumers. The amount of energy generated by sawmills is appropriate to be verified towards sharing the excess heat. Based on Table 11, average costs of electricity incurred by sawmills, taking into account the electricity prices applicable to enterprises in the market, although high, are lower than the value of electricity generated from biomass. Hence, the potential self-sufficiency of sawmills concerning electricity demand. However, in the calculations, $100 \%$ efficiency of power generators was taken into account. Most sawmills, especially those with the smallest processing capacity, either do not own generators or their efficiency is much lower (the latest generation of power generators assume efficiency of approximately 90\%). Moreover, due to the low level of processing of the input material and, consequently, very high material costs incurred by sawmills, at the level of up to $60 \%$, buying a generator can be considered a financial burden for small companies. Nevertheless, with rising energy prices, such an investment might be economically justified. In turn, medium-size and large plants have the potential to secure industrial heat and convert thermal energy into electricity and also to transfer significant surpluses of energy to the local market. Biomass utilization rates are strongly correlated with modern combustion technologies and by-product processing types. The processing of wood chips and sawdust increases the performance indicators for high-temperature biomass combustion and enables its high-efficiency application in the energy systems of wood industries [44,45]. Hence, the main entities that can transfer heat and electricity outside of the company are sawmills with a processing capacity of wood raw material over $50,000 \mathrm{~m}^{3}$ per year.

Figure 3 presents the correlation between the electricity demand in plants and the energy potential of the produced biomass. The ratio indicates a strong Pearson's r correlation for $\mathrm{r}=0.959$ and a significance level of $p=0.041$. The above indicates the compatibility of balancing the available energy potential to the level of demand for co-generation of electricity with a significant share of recovery of industrial heat or heat for the local market. 
However, in the simulation analysis, the level of investment costs associated with converting energy generated during the combustion of biomass into electricity is not taken into account, also, the share of consumption of industrial heat for drying and maintenance of the necessary operating conditions in the plant is not considered. Nevertheless, the analysis indicates the energy potential necessary to balance the demand of plants with regards to electricity and heat energy while maintaining a surplus of raw material for distribution in wood panel plants. The surplus of heat and electricity not allocated for technological needs may constitute an added value in the energy balance of the local market.

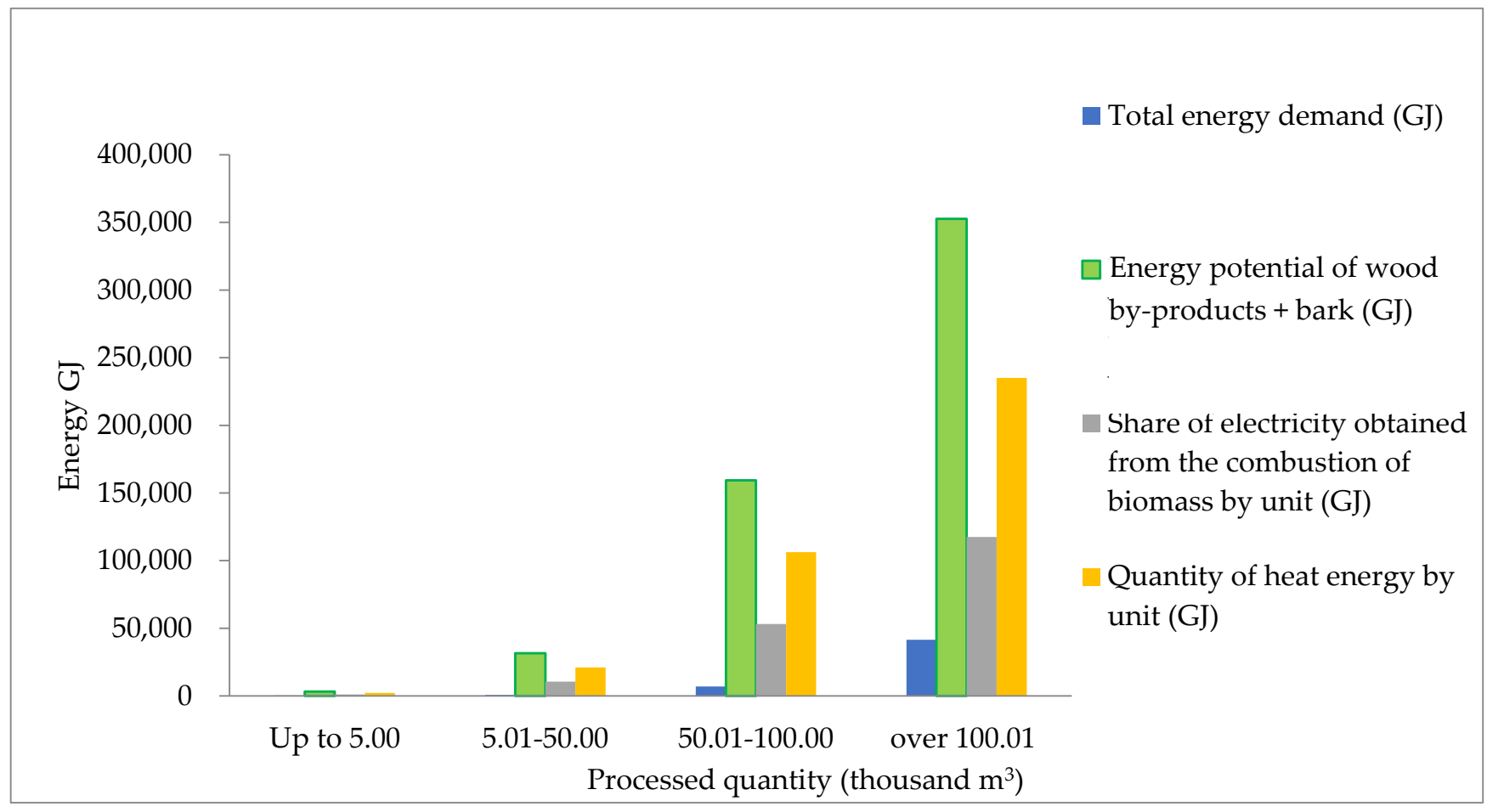

Figure 3. The ratio of electricity demand and potential use of biomass for energy and heat purposes.

The decision to incinerate waste or by-products generated during production is based on both economic and logistical considerations. Hence, not only should the costs of storing wood material for energy purposes, loading or transport be taken into account, but also the possibility of the performance of such operations. By limiting the area to which "green energy" is transferred for customers who live near the processing plant, in addition to the reduction of the aforementioned costs, it is possible to assume easier management of such an area in terms of energy demand. It is worth emphasising that certain decisions and actions taken by the management of enterprises in the circular economy give a boost to small communities. The effects of those actions are noticeable in the place of residence, e.g., in the form of a lower level of environmental pollution. Specific activities of enterprises combined with educating society and the introduction of tools enabling or facilitating the implementation of such changes may contribute not only to better living conditions in the area but also to the improvement of environmental parameters on a macro scale. Such solutions prove that certain economic activities can be performed on a smaller scale for global benefit.

The generation of energy from wood biomass in sawmills demonstrates the possibility of the implementation of such solutions in other wood industries. However, the amount of energy that can be allocated to the needs of the local community will depend mainly on the level of technological development and the size of the plants. Regardless of the possibility of local support of wood enterprises with regards to energy, it is always possible to manage 
post-production waste and by-products in such a way as to ensure a circular flow of raw material and energy independence of companies that process wood.

Author Contributions: Conceptualization, K.M. methodology, K.M.; software, M.W.; validation, M.W.; formal analysis, K.M.; investigation, K.M.; resources, M.W.; data curation, M.W.; writingoriginal draft preparation, K.M.; writing-review and editing, K.M.; visualization, M.W.; supervision, M.W.; project administration, K.M.; funding acquisition, K.M. All authors have read and agreed to the published version of the manuscript.

Funding: This research received no external funding.

Institutional Review Board Statement: Not applicable.

Informed Consent Statement: Not applicable.

Data Availability Statement: Data is contained within the article.

Acknowledgments: This publication was financed from the funds of the Faculty of Economics of the Poznań University of Life Sciences.

Conflicts of Interest: The authors declare no conflict of interest.

\section{References}

1. Readiness for the Future of Production Report 2018 in Collaboration with Kearney, A.T. Available online: https:/ /www3.weforum. org/docs/FOP_Readiness_Report_2018.pdf (accessed on 16 September 2021).

2. Forests and Agriculture. Available online: www.ec.europa.eu/clima/policies/forest_en (accessed on 16 September 2021).

3. Daian, G.; Ozarska, B. Wood waste management practices and strategies to increase sustainability standards in the Australian wooden furniture manufacturing sector. J. Clean. Prod. 2009, 17, 1594-1602. [CrossRef]

4. International Action on Climate Change. Available online: https://ec.europa.eu/clima/eu-action/international-action-climatechange_en (accessed on 16 September 2021).

5. Gillabel, J.; Manshoven, S.; Grossi, F.; Mortensen, L.F.; Coscieme, L. Business Models in a Circular Economy, Eionet Report 2021-ETC/WMGE 2021/2. European Topic Centre on Waste and Materials in a Green Economy Boeretang 200 BE-2400 Mol. Available online: https:/ / www.readkong.com/page/business-models-in-a-circular-economy-eionet-2651252 (accessed on 16 September 2021).

6. Gonzalez, E.D.S.; Koh, L.; Leung, J. Towards a circular economy production system: Trends and challenges for operations management. Int. J. Prod. Res. 2019, 57, 7209-7218. [CrossRef]

7. Lieder, M.; Rashid, A. Towards circular economy implementation: A comprehensive review in context of manufacturing industry. J. Clean. Prod. 2016, 115, 36-51. [CrossRef]

8. Bell, J.E.; Mollenkopf, D.A.; Stolze, H.J. Natural resource scarcity and the closed-loop supply chain: A resource-advantage view. Int. J. Phys. Distrib. Logist. Manag. 2013, 43, 351-379. [CrossRef]

9. European Commission. CASCADES: Study on the Optimised Cascading Use of Wood; Mantau, U., Vis, M., Allen, B., Eds.; Publications Office: Luxembourg, 2016.

10. Kaskadowe Wykorzystanie Drewna. Available online: https://www.encyklopedialesna.pl/haslo/kaskadowe-wykorzystaniedrewna/ (accessed on 16 September 2021).

11. Valavanidis, A. Concept and Practice of the Circular Economy. Turning Goods at the End of their Service Life into Resources, Closing Loops in Industrial Ecosystems and Minimizing Waste. Available online: http:/ / chem-tox-ecotox.org/wp-content/ uploads /2018/07/CIRCULAR-ECONOMY-REVIEW-JULY2018.pdf (accessed on 16 September 2021).

12. Neykov, N.; Antov, P.; Savov, V. Circular Economy Opportunity es for Economic Efficiency Improvement in Wood-Based Panel Industry. In Proceedings of the 11th International Scientific Conference "Business and Management 2020", Vilnius, Lithuania, 7-8 May 2020; Section: Smart Economic Development. Available online: https://www.researchgate.net/publication/34207095 8_Circular_Economy_Opportunities_for_Economic_Efficiency_Improvement_in_Wood-based_Panel_Industry (accessed on 16 September 2021). [CrossRef]

13. Risse, M.; Weber-Blaschke, G.; Richter, K. Resource efficiency of multifunctional wood cascade chains using LCA and exergy analysis, exemplified by a case study for Germany. Resour. Conserv. Recycl. 2017, 126, 141-152. [CrossRef]

14. Van Ewijk, S.; Stegemann, J. Limitations of the waste hierarchy for achieving absolute reductions in material throughput. J. Clean. Prod. 2016, 132, 122-128. [CrossRef]

15. Dammer, L.; Bowyer, C.; Breitmayer, E.; Eder, A.; Nanni, S.; Allen, B.; Carus, M.; Essel, R. Mapping Study on Cascading Use of Wood Products; Formerly World Wildlife Fund: Gland, Switzerland, 2016; Available online: http:/ / awsassets.panda.org/downloads / cascading_use_of_wood_web.pdf (accessed on 23 September 2021).

16. Circular Economy in Construction and the Role of Timber. Available online: https://woodforgood.com/news-and-views/2020 /07/29/encompassing-the-circular-economy/ (accessed on 4 October 2021). 
17. Sustainability Report. 2020. Available online: https://www.bp.com/content/dam/bp/business-sites/en/global/corporate/ pdfs/sustainability/group-reports/bp-sustainability-report-2020.pdf (accessed on 15 October 2021).

18. Anderson, J.-O.; Westerlund, L. Improved energy efficiency in sawmill drying system. Appl. Energy 2014, 113, 891-901. [CrossRef]

19. Climate \& Energy Framework. Available online: https:/ /ec.europa.eu/clima/eu-action/climate-strategies-targets/2030-climateenergy-framework_pl (accessed on 23 October 2021).

20. Malat'ák, J.; Velebil, J.; Bradna, J.; Gendek, A.; Tamelová, B. Evaluation of Co and Nox Emissions in Real-Life Operating Conditions of Herbaceous Biomass Briquettes Combustion. Acta Technol. Agric. 2020, 23, 53-59. [CrossRef]

21. Souček, J.; Jasinskas, A. Assessment of the Use of Potatoes as a Binder in Flax Heating Pellets. Sustainability 2020, $12,10481$. [CrossRef]

22. Cardoso, J.; Silva, V.; Eusébio, D. Techno-economic analysis of a biomass gasification power plant dealing with forestry residues blends for electricity production in Portugal. J. Clean. Prod. 2019, 212, 741-753. [CrossRef]

23. Skanderová, K.; Malat'ák, J.; Bradna, J. Energy use of compost pellets for small combustion plants. Agron. Res. 2015, 13, 413-419.

24. Demirbas, A. Combustion characteristics of different biomass fuels. Prog. Energy Combust. Sci. 2004, 30, 219-230. [CrossRef]

25. Bridgwater, A.; Toft, A.; Brammer, J. A techno-economic comparison of power production by biomass fast pyrolysis with gasification and combustion. Renew. Sustain. Energy Rev. 2002, 6, 181-246. [CrossRef]

26. Raport o Stanie Lasów w Polsce. 2019. Available online: https://www.bdl.lasy.gov.pl/portal/Media/Default/Publikacje/raport_ O_stanie_lasow_2019.pdf (accessed on 23 October 2021).

27. Tao, G.; Geladi, P.; Lestander, T.A.; Xiong, S. The effect of bark content on quality parameters of Scots pine (Pinus sylvestris L.) pellets. Renew. Sustain. Energy Rev. 2012, 16, 3507-3522. [CrossRef]

28. Encyklopedia Lasy Polskie. Available online: https:/ / www.encyklopedia.lasypolskie.pl/doku.php (accessed on 25 October 2021).

29. Energetyka Cieplna w Liczbach (Thermal Power Industry in Numbers). 2015. Available online: https:/ / www.ure.gov.pl/pl/ cieplo/energetyka-cieplna-w-1/6679,2015.html (accessed on 25 October 2021).

30. Energetyka Cieplna w Liczbach (Thermal Power Industry in Numbers). 2016. Available online: https:/ /www.ure.gov.pl/pl/ cieplo/energetyka-cieplna-w-1/7171,2016.html (accessed on 25 October 2021).

31. Energetyka Cieplna w Liczbach (Thermal Power Industry in Numbers). 2017. Available online: https://www.ure.gov.pl/pl/ cieplo/energetyka-cieplna-w-1/7662,2017.html (accessed on 25 October 2021).

32. Energetyka cieplna w Liczbach (Thermal Power Industry in Numbers). 2018. Available online: https://www.ure.gov.pl/pl/ cieplo/energetyka-cieplna-w-1/8386,2018.html (accessed on 25 October 2021).

33. Energetyka Cieplna w Liczbach (Thermal Power Industry in Numbers). 2019. Available online: https://www.ure.gov.pl/pl/ cieplo/energetyka-cieplna-w-1/9009,2019.html (accessed on 25 October 2021).

34. Statistical Yearbook of Forestry. 2020. Available online: https://www.bdl.lasy.gov.pl/portal/Media/Default/Publikacje/GUS_ lesnictwo_2020.pdf (accessed on 27 October 2021).

35. Rocznik Statystyczny Leśnictwa. 2018. Available online: https://stat.gov.pl/obszary-tematyczne/roczniki-statystyczne/rocznikistatystyczne/rocznik-statystyczny-lesnictwa-2018,13,1.html (accessed on 27 October 2021).

36. Forestry. 2016. Available online: https://www.bdl.lasy.gov.pl/portal/Media/Default/Publikacje/GUS_lesnictwo_2016.pdf (accessed on 27 October 2021).

37. Forestry. 2015. Available online: https://stat.gov.pl/files/gfx/portalinformacyjny/pl/defaultaktualnosci/5510/1/11/1/ lesnictwo.pdf (accessed on 27 October 2021).

38. Stanowisko Lasów Państwowych w Sprawie Ogłoszenia Organizacji Przemysłu Drzewnego. Available online: https:/ /www.lasy. gov.pl/pl/kontakt/komunikaty/stanowisko-lasow-panstwowych-w-sprawie-ogloszenia-organizacji-przemyslu-drzewnego (accessed on 27 October 2021).

39. Wieruszewski, M.; Trociński, A.; Kawalerczyk, J. The effect of raw material selection on material efficiency indicators in large-sized roundwood processing. Acta Sci. Pol. Silv. Colendar. Rat. Ind. Lignar. 2020, 19, 105-112. [CrossRef]

40. Mirski, R.; Trociński, A.; Kawalerczyk, J.; Wieruszewski, M. Pine Logs Sorting as a Function of Bark Thickness. Forests 2021, 12, 893. [CrossRef]

41. Estimated Quantity of Generated Wood by-Products. Available online: https://www.encyklopedia.lasypolskie.pl/doku.php?id= p:procentowy-udzial-kory-w-drewnie-dluzycowym (accessed on 29 October 2021).

42. Quantity of Processed Wood and by-Products. Available online: https://www.lasy.gov.pl/pl/drewno (accessed on 3 November 2021).

43. Available online: https://www.ure.gov.pl/pl/urzad/informacje-ogolne/aktualnosci/9791,W-drugim-kwartale-2021-rokusrednia-cena-sprzedazy-energii-elektrycznej-na-rynku.html (accessed on 10 December 2021).

44. Jia, Y.; Wang, Y.; Zhang, Q.; Rong, H.; Liu, Y.; Xiao, B.; Guo, D.; Laghari, M.; Ruan, R. Gas-carrying enhances the combustion temperature of the biomass particles. Energy 2021, 239, 121956. [CrossRef]

45. Nussbaumer, T. Combustion and Co-combustion of Biomass: Fundamentals, Technologies, and Primary Measures for Emission Reduction. Energy Fuels 2003, 17, 1510-1521. [CrossRef] 